\title{
Structural Study of Oxidation Zones on the Gold Alloys for Porcelain Bonding Containing Small Amounts of In and Fe
}

\author{
Hiroki OHNO, Yasuo KANZAWA and Isao KAWASHIMA
}

Department of Dental Materials Science, School of Dentistry, Higashi-Nippon-Gakuen University, Ishikari-Tobetsu, Hokkaido, Japan

Received on March 26, 1984

Gold alloys with $1.5 \mathrm{wt} \%$ total In and Fe were examined by X-ray microanalysis (XMA), X-ray diffraction, and reflection electron diffraction after oxidizing at $1000^{\circ} \mathrm{C}$ for $1 \mathrm{hr}$ in air in order to elucidate the morphological changes in the oxidation zones and the oxidized surface. Internal oxidation particles composed of $\operatorname{In}_{2} \mathrm{O}_{3}$ and Fe-oxides precipitate in needle-like shapes near the oxidized surface and in large clusters at the grain boundaries of the alloy interior. No detectable uniform external oxidation zone by XMA was formed on the alloy containing 1.50 to $0.15 \mathrm{wt} \% \mathrm{In}$ and up to $1.35 \mathrm{wt} \% \mathrm{Fe}$.

Key Words: Oxidation zones, Gold alloys, In-Fe addition

\section{INTRODUCTION}

Small amounts of base metals in gold alloys for porcelain bonding oxidize selectively by high-temperature oxidation during degassing. ${ }^{1)} \quad$ The oxides formed on the alloy surface, in contact with the fused porcelain, are very important in the interface reaction because the oxides improve wetting and adherence between the alloy and porcelain. ${ }^{2,3)}$ Though the base metals added to commercial gold alloys for porcelain bonding are limited to In, $\mathrm{Fe}, \mathrm{Sn}$, and $\mathrm{Ni}^{1}{ }^{1)}$ there are no clearly established criteria for the amounts or kinds of base metals to be added. Basic studies which systematically vary the amounts and kinds of base metals are needed to clarify the effect of these elements since the structural changes of the oxidation zones are affected by both the amounts and kinds of base metals added.

The quantity of the oxides and the morphology of the oxidation zones on gold alloys containing two base metals of $1.5 \mathrm{wt} \%$ total amount, $\mathrm{In}_{-} \mathrm{Sn}^{4-6)}$ and $\mathrm{Fe}-\mathrm{Sn},{ }^{7-9)}$ have been investigated with various experimental techniques by varying the concentration of the base metals. In the present study, gold alloys with $1.5 \mathrm{wt} \%$ total $\mathrm{In}$ and $\mathrm{Fe}$ in various combinations were examined by X-ray microanalysis (XMA), X-ray diffraction, and reflection electron diffraction after oxidizing at $1000^{\circ} \mathrm{C}$ for $1 \mathrm{hr}$ in air in order to shed light on the structure of the oxidation zone.

\section{MATERIALS AND METHODS}

Table 1 shows the compositions $(w t \%)$ of the dental gold alloys used in the experiments. The alloys contained $\mathrm{Au}(85.5 \mathrm{wt} \%), \mathrm{Pt}, \mathrm{Pd}$, and $\mathrm{Ag}$ as noble metals, and In and $\mathrm{Fe}$ as base metals. The In and $\mathrm{Fe}$ content in the alloys totalled $1.5 \mathrm{wt} \%$ and the respective amounts were varied in $0.15 \mathrm{wt} \%$ increments in the 0 to $1.5 \mathrm{wt} \%$ range. All metals used 
Table 1 Composition of the gold alloys in wt \%.

\begin{tabular}{rcccccc}
\hline No. & $\mathrm{Au}$ & $\mathrm{Pt}$ & $\mathrm{Pd}$ & $\mathrm{Ag}$ & $\mathrm{In}$ & $\mathrm{Fe}$ \\
\hline 1 & 85.5 & 6 & 6 & 1 & 1.50 & 0 \\
2 & & & & & 1.35 & 0.15 \\
3 & & & & & 1.20 & 0.30 \\
4 & & & & & 1.05 & 0.45 \\
5 & & & & & 0.90 & 0.60 \\
6 & & & & & 0.75 & 0.75 \\
7 & & & & & 0.60 & 0.90 \\
8 & & & & & 0.45 & 1.05 \\
9 & & & & & 0.30 & 1.20 \\
10 & & & & & 0.15 & 1.35 \\
11 & & & & & 0 & 1.50 \\
\hline
\end{tabular}

were of a purity higher than $99.9 \%$. Weighed amounts of the metals, to give a $10 \mathrm{~g} \mathrm{sam}$ ple, were prepared by melting in an argon gas atmosphere. The samples were melted in an alumina crucible covered with graphite, heated in a high frequency induction furnace. Weight loss by the melting was less than $0.02 \%$.

For morphological observation and X-ray microanalysis* of the oxidation zone, the alloys were cast in $3 \mathrm{~mm} \times 3 \mathrm{~mm} \times 10 \mathrm{~mm}$ ingots by a dental centrifugal casting machine. ${ }^{\dagger}$ The cast specimens were polished metallographically with emery paper and alumina powder and oxidized by heating in an electric furnace at $1000^{\circ} \mathrm{C}$ for $1 \mathrm{hr}$ in air. The oxidized specimens were mounted in metallurgical resin. Cross-section perpendicular to the oxidized surface and cross-sections very close to the oxidized surface $\left(\sim 10^{\circ}\right.$ off $)$ were examined.

Plate specimens, $15 \mathrm{~mm} \times 20 \mathrm{~mm} \times 2 \mathrm{~mm}$, for X-ray diffraction to identify the oxides formed on the alloy surface were made by casting, polishing, and subsequently oxidizing at $1000^{\circ} \mathrm{C}$ for $1 \mathrm{hr}$ in air in a similar manner to that described above. X-ray diffraction was carried out with a diffractometer ${ }^{\ddagger}$ under the conditions of $\mathrm{Cu} \mathrm{K} \alpha$ radiation with $\mathrm{Ni}$ filter, $35 \mathrm{kV}$ tube voltage, and $20 \mathrm{~mA}$ current.

The specimens for the reflection electron diffraction were cast in $9 \mathrm{~mm} \times 0.5 \mathrm{~mm}$ ingots. These specimens were polished metallographically and then oxidized by heating in an electric furnace a $1000^{\circ} \mathrm{C}$ for $1 \mathrm{hr}$ in air. Reflection high energy electron diffraction patterns were taken using an electron microscope $e^{\S}$ with an accelerating voltage of $100 \mathrm{kV}$. The camera constant was calibrated with the transmission diffraction pattern of a gold film immediately before and after taking the reflection patterns of the specimens. The diameter of the diffraction ring measured on the film enlarged the diffraction pattern.

\section{RESULTS}

Figure 1 shows the XMA results of the section perpendicular to the oxidized surface,

* EPMA X-650, Hitachi Seisakusho, Tokyo, Japan.

† J.F. Jelenko Co., Thermotrol-2500, Armonk, NY, USA.

$\ddagger$ Rigaku Denki, Geigerflex 2013, Tokyo, Japan.

$\S$ H-500, Hitachi Seisakusho, Tokyo, Japan. 

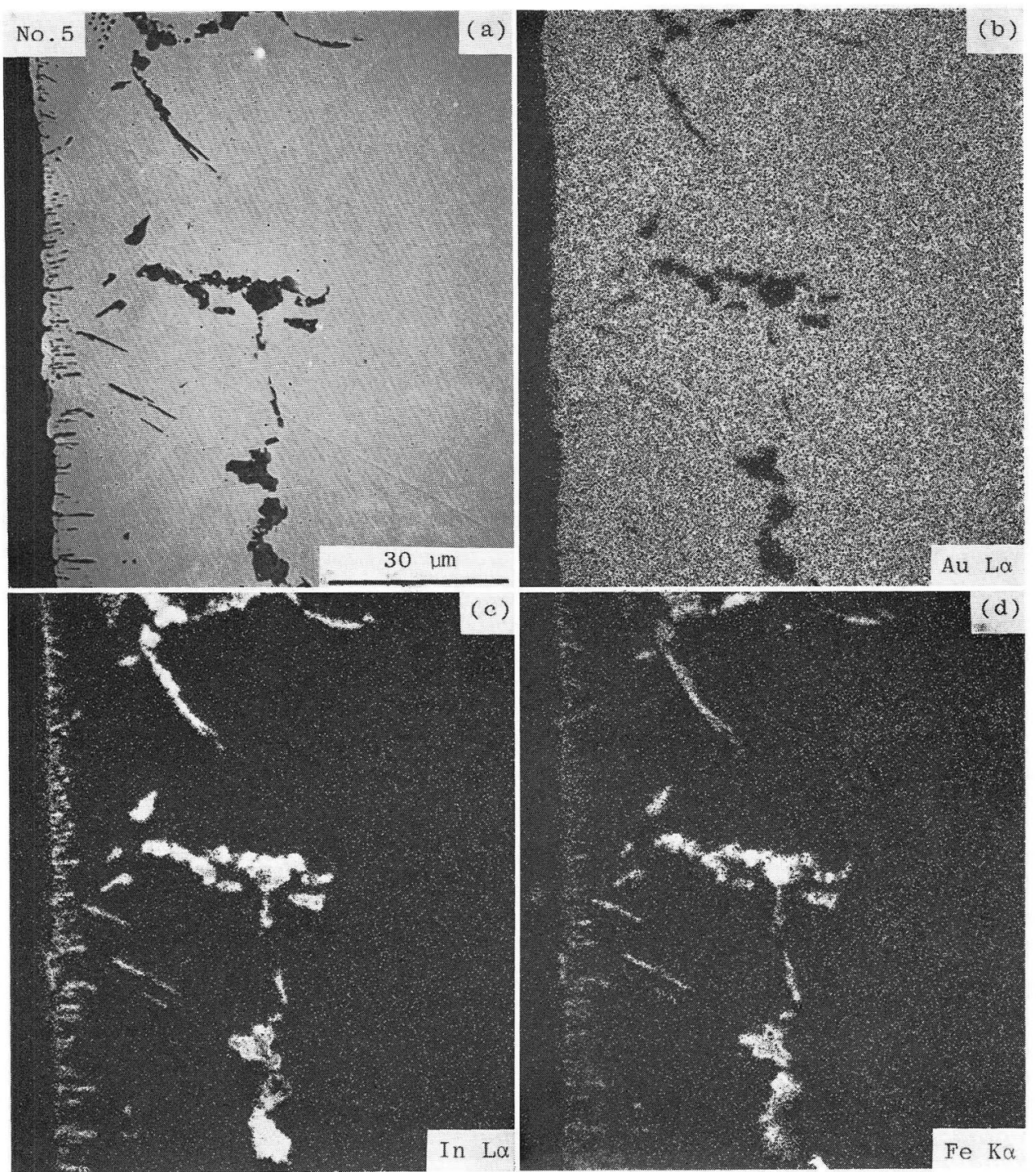

Figure 1 Secondary electron image (a) and X-ray images (b), (c), and (d) formed by Au $\mathrm{L} \alpha$, In $\mathrm{L} \alpha$, and $\mathrm{Fe} \mathrm{K} \alpha$, obtained from perpendicular cross-section to oxidized surface of alloy No. 5 .

obtained from alloy No. 5 containing $0.9 \mathrm{wt} \%$ In and $0.6 \mathrm{wt} \% \mathrm{Fe}$, showing (a) the secondary electron image, (b) the X-ray image formed by $\mathrm{Au} L \alpha$, (c) that for In $\mathrm{L} \alpha$, and (d) that for $\mathrm{Fe} \mathrm{K} \alpha$. The black areas on the left side of (a) is the resin in which the specimen is mounted. No external oxidation zone is observed by the secondary electron and $\mathrm{X}$-ray images. In and $\mathrm{Fe}$ are oxidized internaly as $\mathrm{O} \mathrm{K} \alpha$ radiation is detected in the regions where the two elements are enriched. The shape of the precipitations of In and Fe oxides is needle-like near the oxidized surface and extensive massive in the inner alloy matrix. The illustrated structures in the oxidation zone perpendicular to the oxidized 


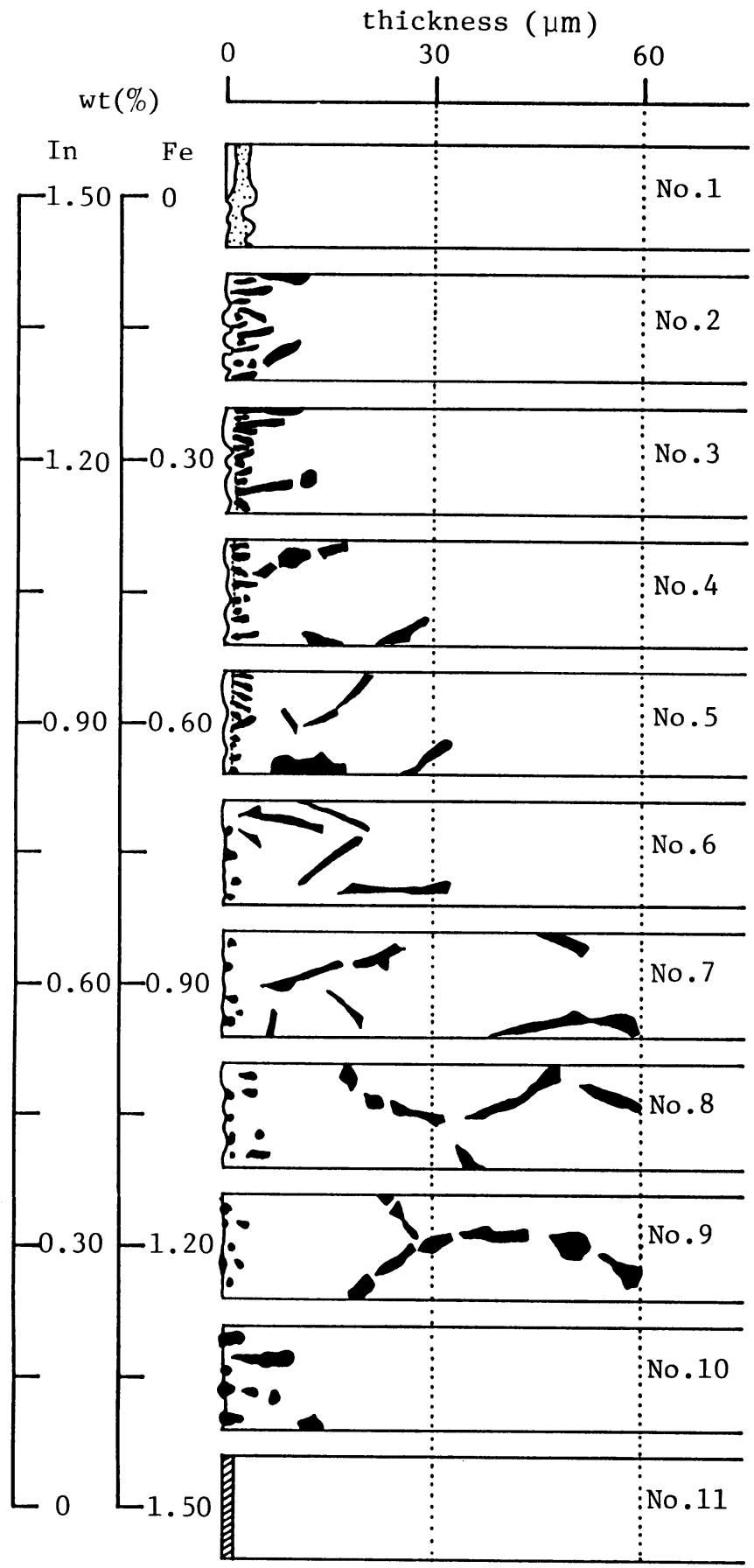

Figure 2 Oxidation zones perpendicular to the oxidized surface, obtained from XMA results. 


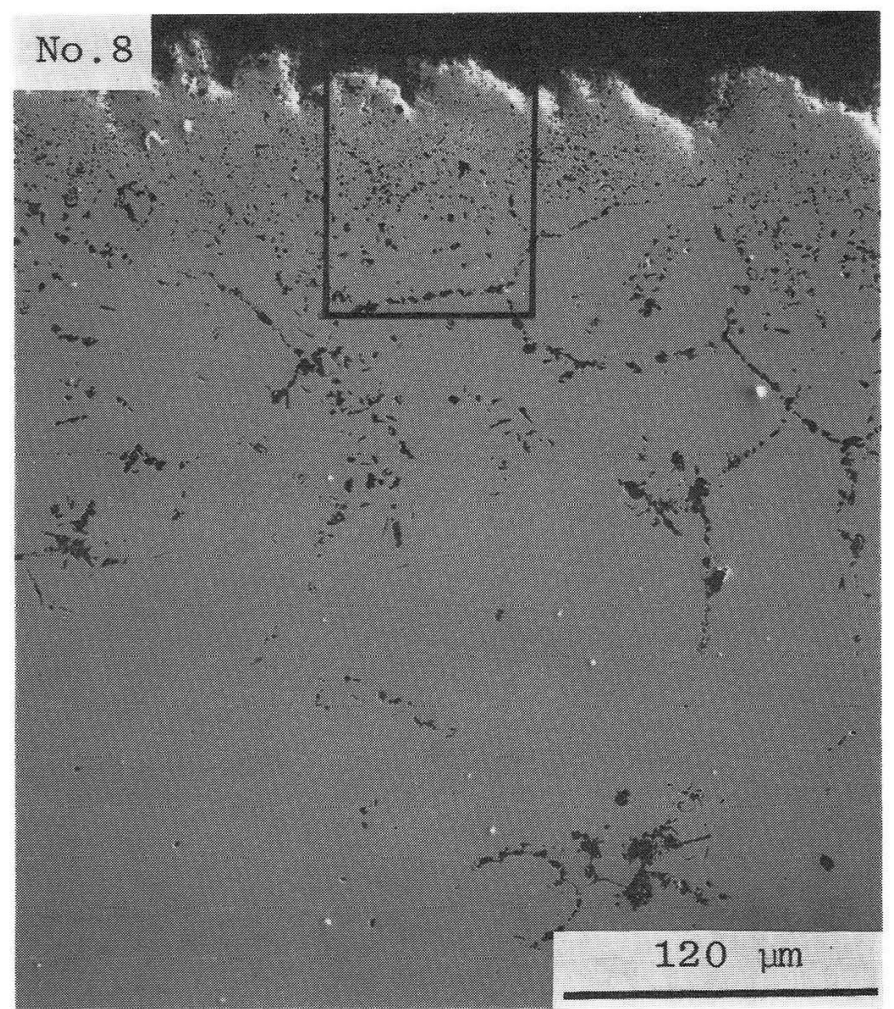

Figure 3 Secondary electron image of the inclined cross-section $\left(10^{\circ} \mathrm{off}\right)$ of alloy No. 8 .

surface of the alloys, obtained by XMA, are summarized in Fig. 2. XMA revealed no external oxidation zone on alloys No. 1 to No. 10 but alloy No. 11 showed an external oxidation zone containing only $\mathrm{Fe}$. The internal oxidation particles precipitated progressively deeper into the alloy matrix from alloy No. 2 to No. 7 to 9 , where they reach the deepest, $\sim 60 \mu \mathrm{m}$.

If a very thin external oxidation zone, which is difficult to detect on perpendicular cross-sections, is formed on the alloy surface, there is a possibility of observing it on an inclined cross-section which enlarges the oxidation zone observed. Figure 3 shows the secondary electron image of a cross-section inclined $10^{\circ}$ to the oxidized surface of alloy No. 8. Very small oxide particles precipitate in the alloy near the oxidized surface. In the deeper alloy matrix, the oxides form preferentially at the grain boundary. The enclosed area near the oxidized surface in Fig. 3 was enlarged and shown in Fig. 4: (a) is the secondary electron image and (b), (c), and (d) arc X-ray images formed by Au L $\alpha$, In $\mathrm{L} \alpha$, and $\mathrm{Fe} \mathrm{K} \alpha$. The characteristic X-rays from the resin substrate appear in the upper part of (a) because the resin is very thin. No external oxidation zone is observed.

Figure 5 shows secondary electron images of oxidized alloy surfaces, (a) obtained from alloy No. 2, (b) from alloy No. 4, (c) from alloy No. 6, and (d) from alloy No. 8. The convex irregular areas shown in (a) and (b) decrease with the increase in Fe content, and 

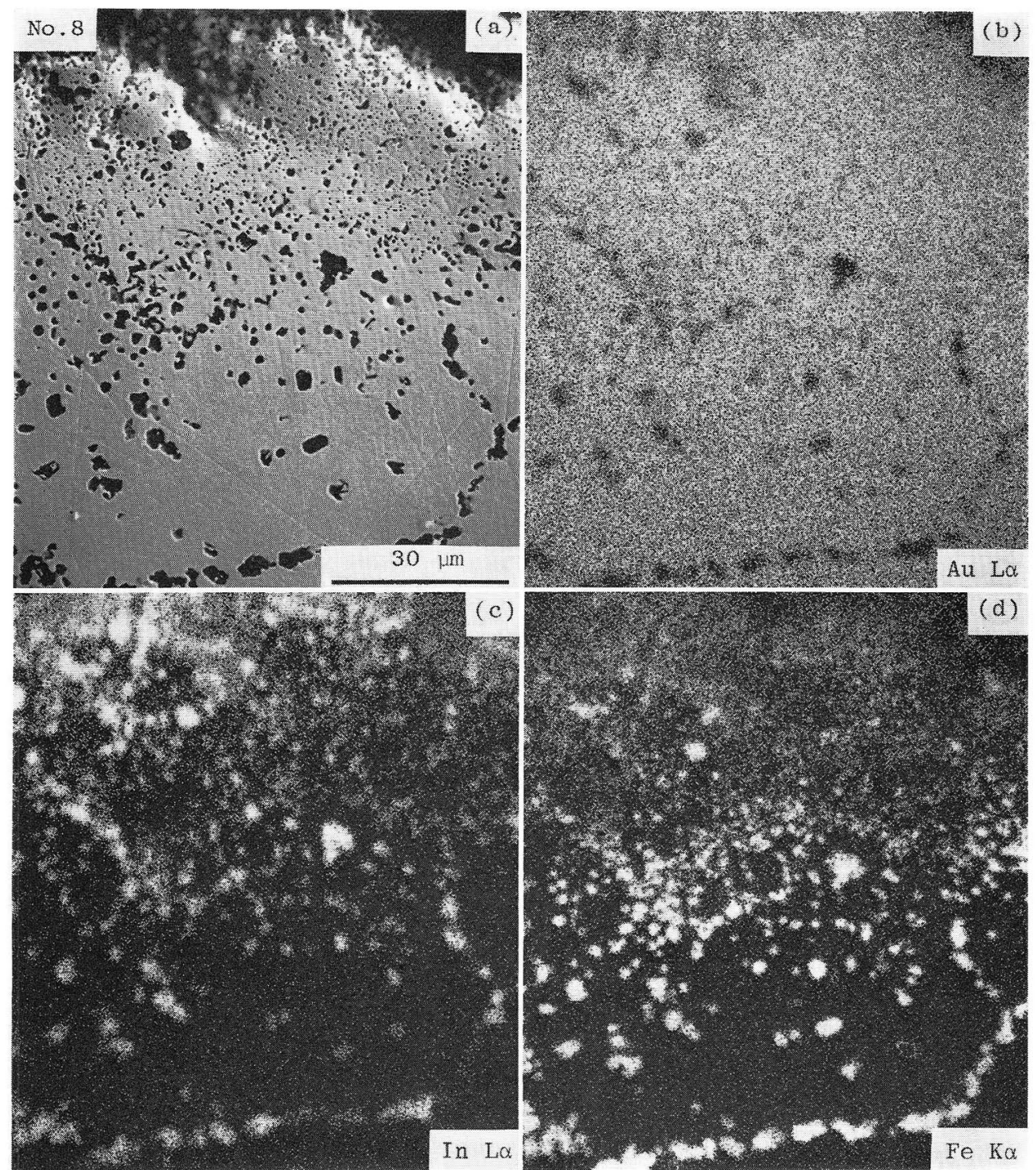

Figure 4 Secondary electron image (a) and X-ray images (b), (c), and (d) formed by Au L $\alpha$, In L $\alpha$, and $\mathrm{Fe} \mathrm{K} \alpha$, obtained from enclosed area in Fig. 3.

in (c) and (d) the surface is covered with small pits. Figure 6 shows the secondary electron image (a), and three characteristic X-ray images, (b), (c), and (d), obtained from alloy No. 4. In and $\mathrm{Fe}$ distribute in the same regions and enrich near the grain boundaries. The convex areas of the grains are rich in Au. The grain boundaries stand out clearly by preferential oxide formation.

X-ray diffraction patterns obtained from the oxidized alloy surfaces are presented in Fig. 7. The diffraction pattern of (a) is from alloy No. 2; (b) is from alloy No. 4; (c) is from alloy No. 6; (d) is from alloy No. 8; and (e) is from alloy No. 10. Diffraction 

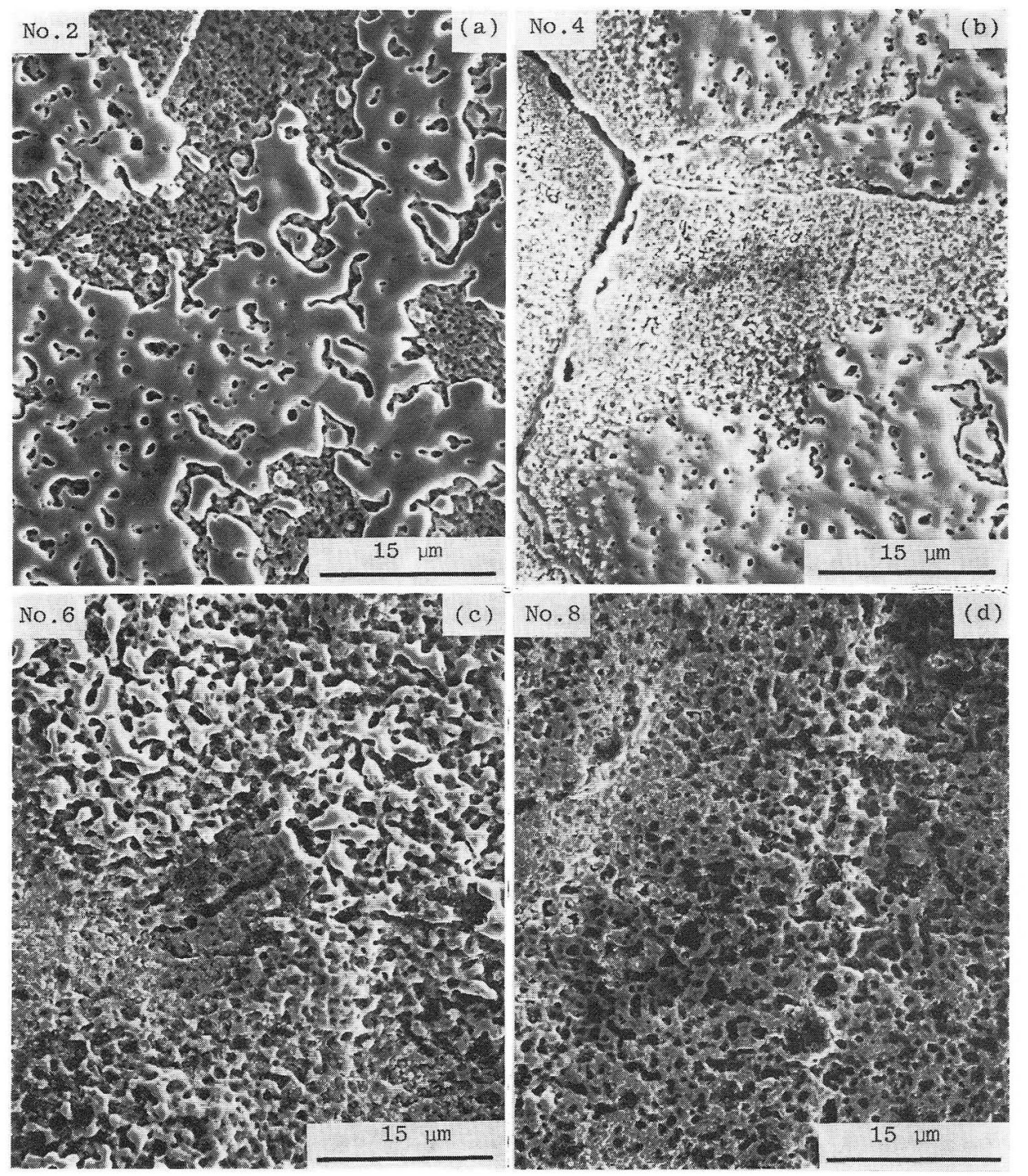

Figure 5 Typical secondary electron images of the oxidized alloy surface, obtained from alloy No. 2 (a), 4 (b), 6 (c), and 8 (d).

pattern (a) shows the $\operatorname{In}_{2} \mathrm{O}_{3}$ crystal and very strong diffraction intensity from the alloy matrix. Alloy No. 4 shows three kinds of reflections, $\mathrm{In}_{2} \mathrm{O}_{3}$, alloy matrix, and traces of a substance (marked by X), in pattern (b) which contains more Fe than alloy No. 2. Substance $\mathrm{X}$ is not identified because $\mathrm{X}$-ray diffraction data for this substance could not be found in the JCPDS cards. The intensities diffracted from substance $\mathrm{X}$ become stronger with increasing $\mathrm{Fe}$ content. However, the unknown $\mathrm{X}$ disappears in alloy No. 11 containing only $\mathrm{Fe}$. Traces of iron oxide, $\mathrm{Fe}_{2} \mathrm{O}_{3}$, appear in the diffraction patterns (d) and (e). 


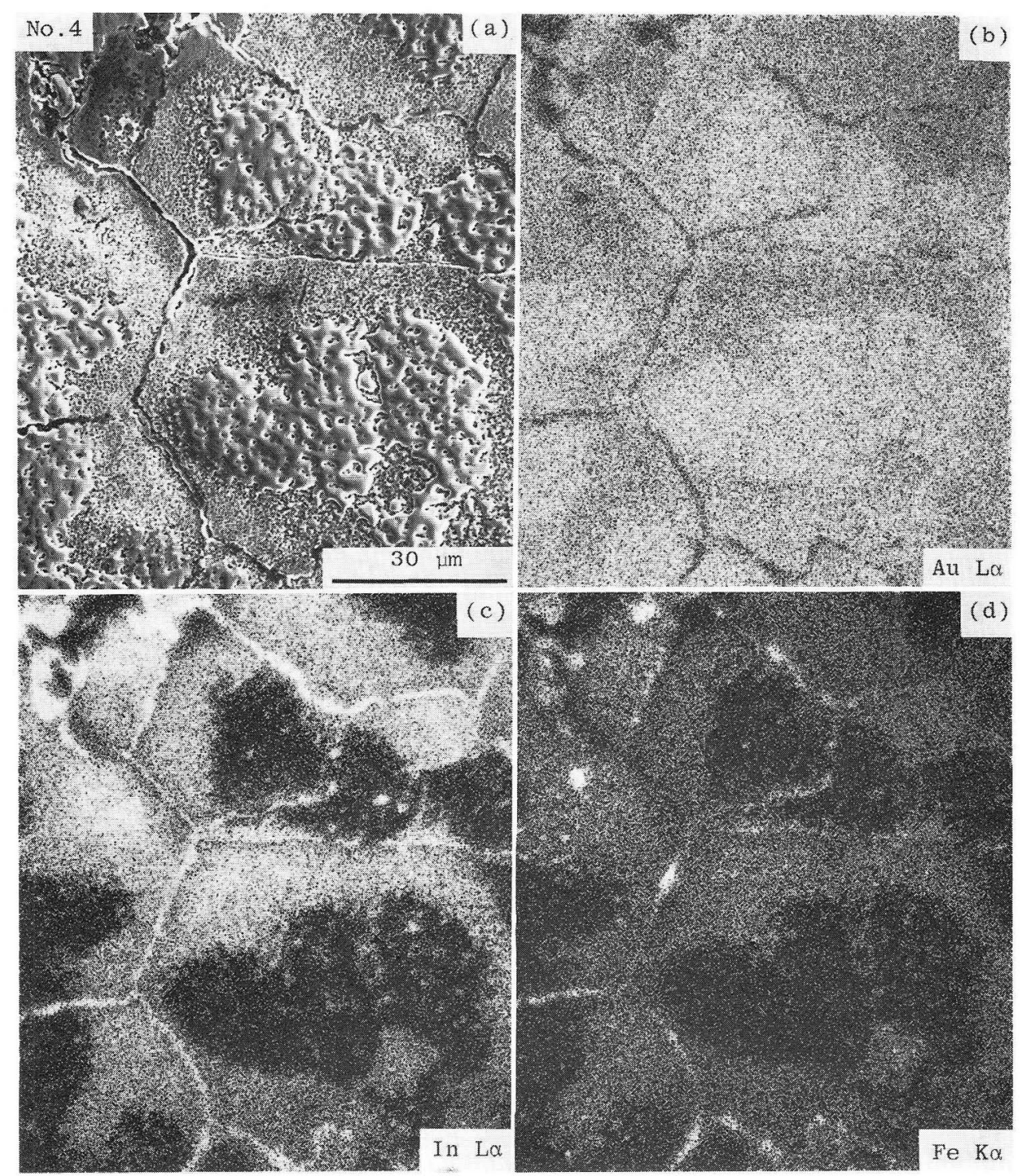

Figure 6 Secondary electron image (a) and X-ray images (b), (c), and (d) formed by Au $\mathrm{L} \alpha$, In $\mathrm{L} \alpha$, and $\mathrm{Fe} \mathrm{K} \alpha$, obtained from the oxidized alloy surface of alloy No. 4.

Figure 8 shows a reflection high energy electron diffraction patterns obtained from the surface of alloy No. 3. In Table 2, the observed lattice spacings and intensities of the diffraction rings are shown and compared with the lattice spacings of the alloy measured by the Deby-Scherrer method and data for $\mathrm{In}_{2} \mathrm{O}_{3}$ from the JCPDS card-index. A comparison with the reference substances shows that diffraction is from both the alloy matrix and $\mathrm{In}_{2} \mathrm{O}_{3}$ : Diffraction from the alloy matrix is identified from the 200 reflection of the matrix, as the 111 reflection of the matrix overlaps the 411 reflection of $\operatorname{In}_{2} \mathrm{O}_{3}$. The diffraction rings from the alloy matrix gives evidence of the exposure of the alloy matrix, 


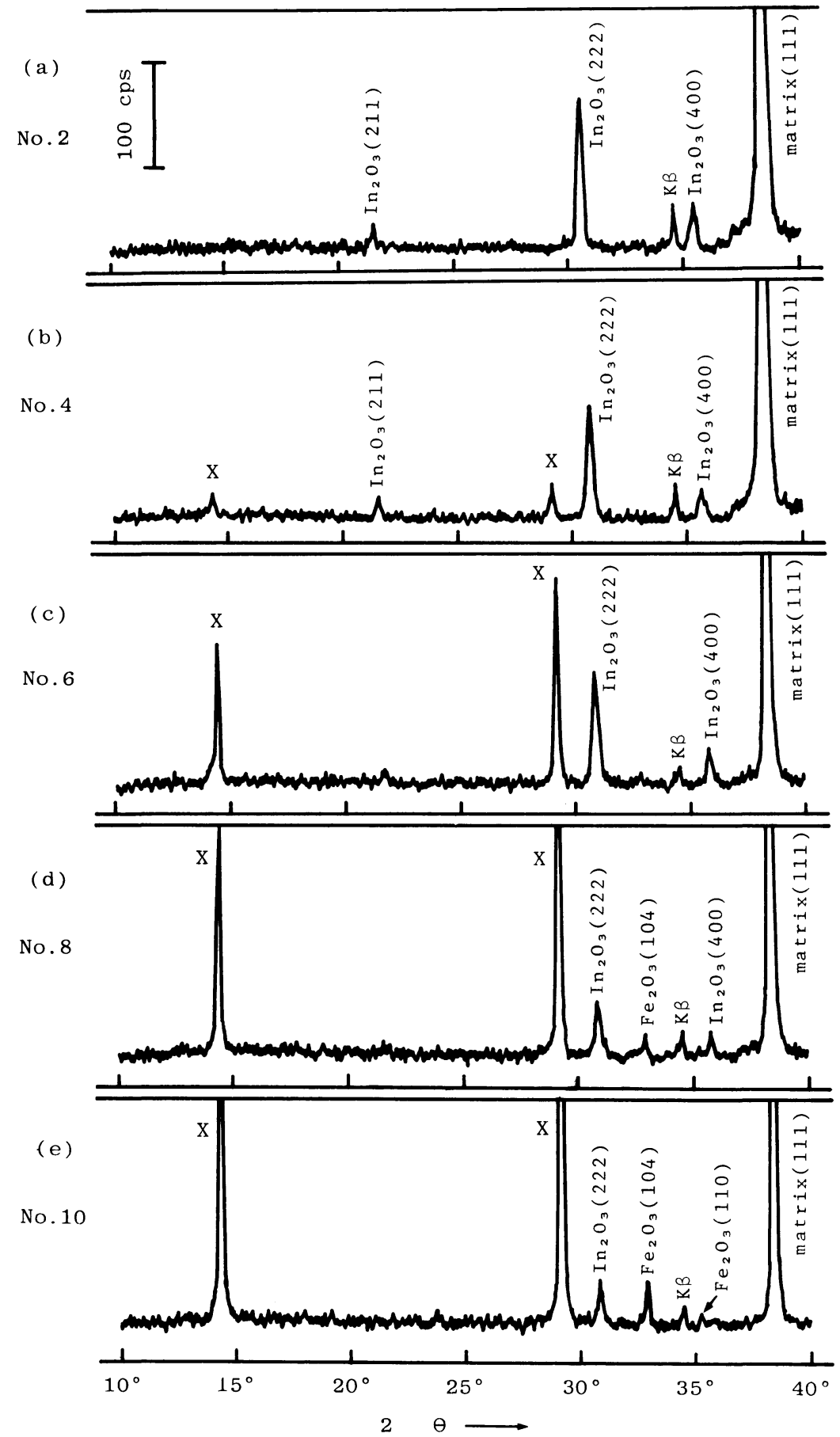

Figure 7 X-ray diffraction patterns obtained from oxidized surface of alloy No. 2 (a), 4 (b), 6 (c), 8 (d), and 10 (e). 


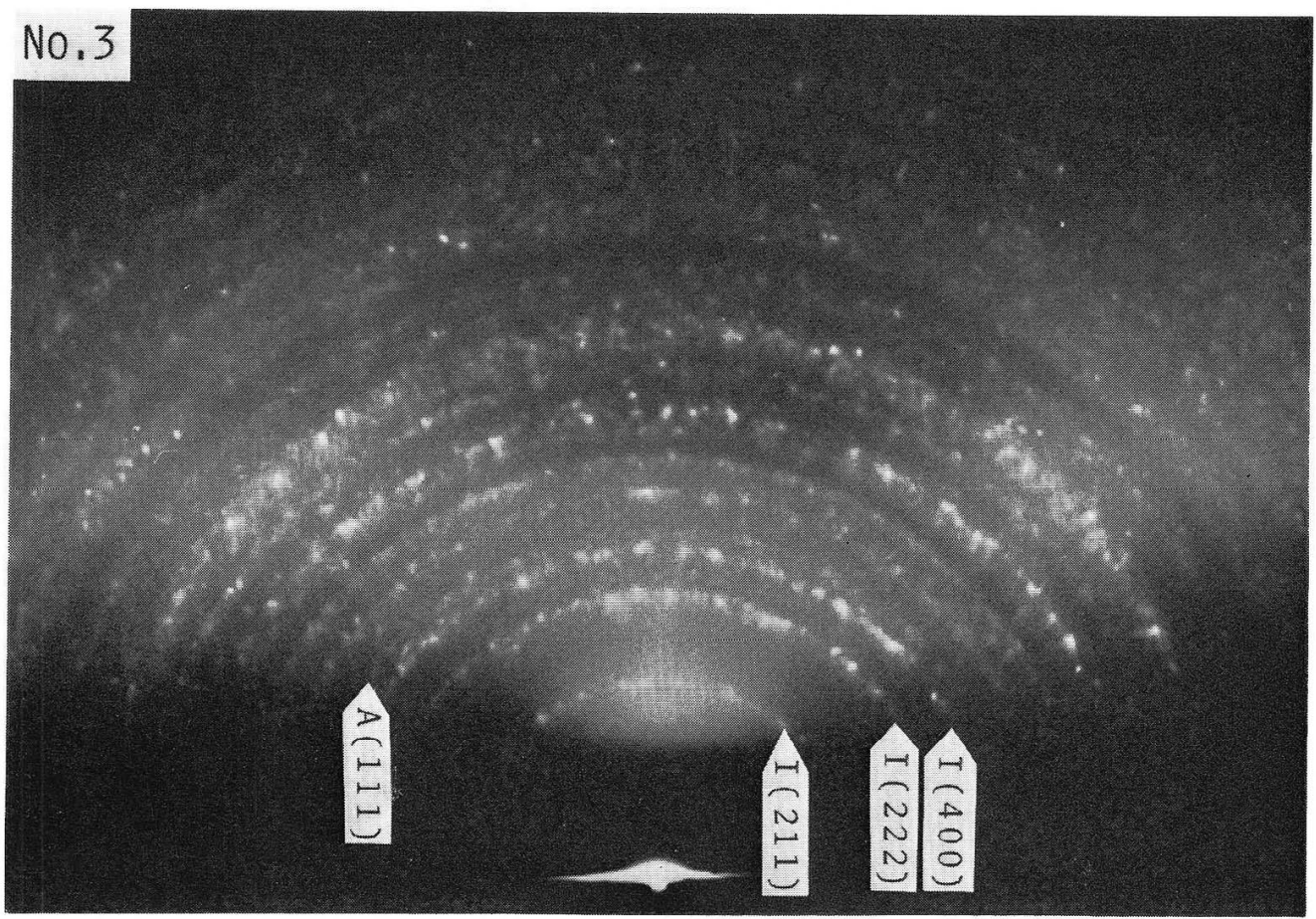

Figure 8 Reflection high energy electron diffraction pattern from the surface of alloy No. 3 . A(111): 111 reflection of alloy matrix; I(211), I(222), and I(400): 221, 222, and 400 reflection of $\mathrm{In}_{2} \mathrm{O}_{3}$.

Table 2 Observed lattice spacings and intensities of reflections obtained from Fig. 8 with those of reference substances.

\begin{tabular}{|c|c|c|c|c|c|c|c|}
\hline \multirow{3}{*}{\multicolumn{2}{|c|}{ Observed values }} & \multicolumn{6}{|c|}{ Reference substances measured by X-rays } \\
\hline & & \multirow{2}{*}{\multicolumn{3}{|c|}{ Alloy }} & \multirow{2}{*}{\multicolumn{3}{|c|}{$\begin{array}{c}\text { JCPDS card } \\
\operatorname{In}_{2} \mathrm{O}_{3}\end{array}$}} \\
\hline & & & & & & & \\
\hline $\mathrm{dA}$ & I & $\mathrm{dA}$ & $\mathrm{I} / \mathrm{I}_{1}$ & hkl & dA & $\mathrm{I} / \mathrm{I}_{1}$ & hkl \\
\hline 4.24 & $\mathrm{~m}$ & & & & 4.13 & 14 & 211 \\
\hline 2.97 & $\mathrm{~s}$ & & & & 2.921 & 100 & 222 \\
\hline 2.55 & $\mathrm{w}$ & & & & 2.529 & 30 & 400 \\
\hline 2.38 & $\mathrm{~m}$ & 2.322 & 100 & 111 & 2.385 & 8 & 411 \\
\hline 2.18 & $\mathrm{~m}$ & & & & 2.157 & 6 & 332 \\
\hline \multirow[t]{3}{*}{2.04} & $\mathrm{~m}$ & 20.14 & 52 & 200 & & & \\
\hline & & & & & 1.984 & 10 & 431 \\
\hline & & & & & 1.848 & 4 & 521 \\
\hline \multirow[t]{4}{*}{1.80} & $\mathrm{~s}$ & & & & 1.788 & 35 & 440 \\
\hline & & & & & 1.735 & 4 & $\left\{\begin{array}{l}530 \\
433\end{array}\right.$ \\
\hline & & & & & 1.641 & 6 & 611 \\
\hline & & & & & 1.561 & 4 & 541 \\
\hline 1.55 & $\mathrm{w}$ & & & & 1.525 & 25 & 622 \\
\hline 1.50 & $\mathrm{w}$ & & & & 1.492 & 6 & 631 \\
\hline 1.45 & vw & 1.427 & 32 & 220 & 1.460 & 6 & 444 \\
\hline
\end{tabular}


revealing the absence of a uniform oxide layer thicker than $100 \AA$.

\section{DISCUSSION}

1. Identification of the formed oxides

Three substances, $\mathrm{In}_{2} \mathrm{O}_{3}, \mathrm{Fe}_{2} \mathrm{O}_{3}$, and an unknown substance $\mathrm{X}$, were observed by $\mathrm{X}$-ray diffraction on the alloys in the present study. Substance $X$ was not detected in the alloys containing only In (No. 1) or only Fe (No. 11), however it was found in the alloys containing both In and $\mathrm{Fe}$, and the amounts increase with increases in $\mathrm{Fe}$ content. It is assumed that the substance is a Fe-oxide soluted In. The existence of substance $\mathrm{X}$ has already been reported by Miyagawa, ${ }^{10}$ ) however, is not listed in the JCPDS cards, and is not described in the $\mathrm{In}_{2} \mathrm{O}_{3}-\mathrm{Fe}_{2} \mathrm{O}_{3}$ binary phase diagram reported by Schneider, et al. ${ }^{11}$ ) In Fig. 7, the lattice spacings which are obtained from two $2 \theta$ sites, $14.45^{\circ}$, and $29.20^{\circ}$, of the intensity peaks diffracted from substance $X$ are calculated to be $6.13 \AA$ and $3.06 \AA$. If the $\mathrm{In}^{3+}$ ions exchange to the $\mathrm{Fe}^{3+}$ sites of the $\mathrm{Fe}_{2} \mathrm{O}_{3}$ crystal, the lattice spacings of the $\mathrm{Fe}_{2} \mathrm{O}_{3}$ may be increased because the ionic radius of $\mathrm{In}^{3+}, 0.81 \AA$, is bigger than that of $\mathrm{Fe}^{3+}$, $0.60 \AA$. However, the lattice spacing of substance $\mathrm{X}, 6.13 \AA$ appears to be too large to be explained in this way, because the largest lattice spacings (hkl) of $\mathrm{FeO}, \mathrm{Fe}_{3} \mathrm{O}_{4}$, and $\mathrm{Fe}_{2} \mathrm{O}_{3}$ are $2.49 \AA$ (111), $4.852 \AA$ (111), and $3.66 \AA(012)$. Therefore, it is concluded that substance $\mathrm{X}$ is an Fe-oxide with a crystal system which is entirely different from the known Fe-oxide crystals.

We attempted to produce this substance to identify its crystal structure: A mixture of $20 \mathrm{wt} \% \mathrm{In}_{2} \mathrm{O}_{3}$ and $80 \mathrm{wt} \%$ Fe-oxide $\left(\mathrm{FeO}, \mathrm{Fe}_{3} \mathrm{O}_{4}\right.$, or $\left.\mathrm{Fe}_{2} \mathrm{O}_{3}\right)$ was melted at over $2000^{\circ} \mathrm{C}$ and the alloy of $20 \mathrm{wt} \%$ In and $80 \mathrm{wt} \%$ Fe was heated at $1000^{\circ} \mathrm{C}$ for $1 \mathrm{hr}$ in air. However, substance $\mathrm{X}$ was not obtained in these experiments, and further studies are necessary to elucidate the crystal structure of substance $X$.

2. Internal oxidation of gold-rich alloys

Meijering ${ }^{13)}$ listed three conditions for internal oxidation of a solute B in a binary alloy A-B: (1) the alloy must have appreciable solubility of oxygen; (2) oxygen must diffuse more rapidly in the solvent $\mathrm{A}$ than in the solute $\mathrm{B}$; $(3)$ the oxygen affinity of element B must be considerably greater than that of element A. The gold alloys investigated here do not satisfy the first and second requirements because the solubility of oxygen is very small in an alloy containing $85.5 \mathrm{wt} \% \mathrm{Au}$. Under these conditions Meijering reported that no extensive internal oxidation of gold-rich alloys can be expected.

Wagner ${ }^{13)}$ has proposed that when the diffusion rate of the base metal through the external oxidation zone is faster than that of the base metal in the alloy matrix, the results may be a rugged alloy/oxide interface and finally spikes as observed in $\mathrm{Au}-\mathrm{Cu}$ alloys. $\mathrm{He}$ does not classify this phenomena as internal oxidation because oxygen dissolution and diffusion through the alloy is not involved. However, observations by XMA have shown that internal oxidation occurs in gold-rich alloys. ${ }^{1,4,6-9,14)}$ The mechanism of the internal oxidation of the gold-rich alloys is essentially different from an oxidation satisfying the above conditions. In gold alloys $\left(85.5 \mathrm{wt} \%\right.$ ) containing small amounts of $\mathrm{Fe}$ and $\left.\mathrm{Sn},{ }^{7,8}\right)$ an internal oxides of $\mathrm{Fe}_{2} \mathrm{O}_{3}$ and $\mathrm{SnO}_{2}$ precipitated as a network along the grain boundaries. The internal oxidation mechanism for gold-rich alloys with oxidation along the grain bound- 
aries has been explained by $\mathrm{Fe}_{2} \mathrm{O}_{3}$ preferentially diffusing oxygen rather than $\mathrm{Fe}$ ions, and so $\mathrm{Fe}_{2} \mathrm{O}_{3}$ acts as a diffusion path into the alloy interior. Further, in gold alloys containing In and $\mathrm{Sn}$, internal oxidation has been also observed and explained by $\operatorname{In}_{2} \mathrm{O}_{3}$ preferentially diffusing oxygen ions to the alloy interior through the $\operatorname{In}_{2} \mathrm{O}_{3}$ precipitated at the grain boundaries. $^{4)}$

By observation of the cross-section, perpendicular to the oxidized surface, in Fig. 1, the minute needle-like internal oxides nearest the oxidized surface and the gross precipitation in the alloy interior means that oxygen does not have uniform solubility in the alloy matrix. The oxides may precipitate at the discontinuities in crystal structure such as grain boundaries, sub-grain boundaries, and dislocations. The internal oxidation of the gold alloys studied here may take place with this mechanism, with the formed oxides acting as diffusion paths to the alloy interior.

The depth of the internal oxidation increases with increasing Fe content as shown in Fig. 2. It has been observed with other gold alloys $(85.5 \mathrm{wt} \% \mathrm{Au})$ that the depth reaches maximum at a certain concentration of added elements: The depth for gold alloys containing In and $\mathrm{Sn}^{4)}$ and $\mathrm{Fe}$ and $\mathrm{Sn}^{9)}$ is $20 \mu \mathrm{m}$ and $5 \mu \mathrm{m}$. The increased depth, $60 \mu \mathrm{m}$, observed in the alloys in this study, shows that oxygen penetrates more easily here. The maximum depth changes with changes in the crystal inperfections induced by the added elements.

3. Absence of an external oxide layer and the morphology of the oxidized alloy surface.

In gold alloys containing 1.50 to $0.15 \mathrm{wt} \%$ In and up to $1.35 \mathrm{wt} \% \mathrm{Fe}$ (alloy No. 1 to No. 10), oxidized at $1000^{\circ} \mathrm{C}$ for $1 \mathrm{hr}$ in air, XMA demonstrated that no detectable uniform external oxidation zone was formed on the alloy surface. This finding was confirmed by reflection electron diffraction on alloy No. 3. However, the possible existence of both a very thin oxide layer (less than $100 \AA$ ) and a non-crystalline oxide layer on the alloy surface can not be established by electron diffraction. In the gold alloy $(85.5 \mathrm{wt} \% \mathrm{Au})$ containing $0.9 \mathrm{wt} \%$ In and $0.6 \mathrm{wt} \% \mathrm{Sn}$, ESCA measurements have shown that the alloy surface is not covered by a very thin layer but is partially exposed. ${ }^{6}$ ) Though, this was not confirmed by ESCA in the present study, it appears that no surface oxide layer is present on the alloy, No. 1 to No. 10. Pethe, et al. have reported that if concentrations of the alloying element is increased above a certain critical value, a transition from internal to external oxidation occurs. It may be assumed that the base metal content of the alloys here is below the critical level necessary for the formation of an external oxidation zone.

In Pd-Ag alloys containing In and $\mathrm{Sn}$ for porcelain bonding nodules composed of Pd-Ag alloy was reported on the oxidized alloy surface after heating to $650^{\circ} \mathrm{C}-1010^{\circ} \mathrm{C}$ in air but no surface oxides were detected by Auger electron spectroscopy and X-ray powder diffractometry. ${ }^{16)}$ The mechanism of formation of the nodules has been explained by the Nabarro-Herry creep mechanism in which Pd-Ag alloy is extruded by the pressure induced by volume increments from the metallic states changing to internal oxides of In and Sn. These nodules form preferentially on the alloy grain surface, they avoid the grain boundaries, and coalesce at high temperatures. The coalesced nodules was observed at the interface of resin and alloy in Fig. 1 (a) and also in the former reports. ${ }^{1,4)}$ 


\section{CONCLUSIONS}

The morphological changes in both the oxidation zones and the oxidized surface of gold alloys $(85.5 \mathrm{wt} \% \mathrm{Au})$ with $1.5 \mathrm{wt} \%$ total In and Fe were examined by X-ray microanalysis, X-ray diffraction, and reflection electron diffraction after oxidizing at $1000^{\circ} \mathrm{C}$ for $1 \mathrm{hr}$ in air.

XMA showed no detectable uniform external oxidation zone on the alloys containing 1.50 to $0.15 \mathrm{wt} \%$ In and up to $1.35 \mathrm{wt} \% \mathrm{Fe}$, showing that the alloy matrix is partially exposed on the surface. This was confirmed by reflection electron diffraction on the alloy containing $1.20 \mathrm{wt} \%$ In and $0.30 \mathrm{wt} \% \mathrm{Fe}$. Three oxides, $\mathrm{In}_{2} \mathrm{O}_{3}, \mathrm{Fe}_{2} \mathrm{O}_{3}$, and an unknown Fe-oxide were formed on the alloys containing In and $\mathrm{Fe}$, and they precipitate in needlelike shapes near the oxidized surface and become extensive massive at the grain boundaries of the alloy interior.

Internal oxidation may occur by a mechanism in which the formed oxides act as diffusion paths which permit the penetration of oxygen to the alloy interior.

\section{REFERENCES}

1) Ohno, H., Miyakawa, O., Watanabe, K., and Shiokawa, N.: The structure of oxide formed by high-temperature oxidation of commercial gold alloys for porcelain-metal bonding, J. Dent. Res., 61: $1255-1262,1982$.

2) King, B.W., Tripp, H.P., and Duckworth, W.H.: Nature of adherence of porcelain enamels to metals, J. Ameri. Ceram. Soc., 42: 504-525, 1959.

3) Borom, M.P. and Pask, J.A.: Role of "adherence oxides" in the development of chemical bonding at glass-metal interfaces, J. Ameri. Ceram. Soc., 49: 1-6, 1966.

4) Ohno, H., Kanzawa, Y., Kawashima, I., and Shiokawa, N.: Structure of high-temperature oxidation zones of gold alloys for metal-porcelain bonding containing small amounts of In and Sn, J. Dent. Res., 62: 774-779, 1983.

5) Ohno, H., Kanzawa, Y., Kawashima, I., Yamane, Y., and Takanohashi, S.: A basic study to clarify the porcelain-metal bonding mechanism - Analysis of the oxidized surface of gold alloys by reflection electron diffraction-, Higashi Nippon Dent. J., 1: 129-139, 1982.

6) Ohno, H., Kanzawa, Y. and Yamane, Y.: ESCA study on the oxidized surface of a gold alloy for porcelain-metal bonding, Dent. Mat. J., 2: 59-67, 1983.

7) Ohno, H. and Kanzawa, Y.: Internal oxidation in gold alloys containing small amounts of Fe and Sn, J. Mat. Sci., 18: 919-929, 1983.

8) Ohno, H. and Kanzawa, Y., Takanohashi, S.: State analysis of iron oxides formed on gold alloys for porcelain-metal bonding by an X-ray microanalyzer, Dent. Mat. J., 2: 179-191, 1983.

9) Ohno, H. and Kanzawa, Y.: Structural changes in the oxidation zones of gold alloys for porcelain bonding containing small amounts of $\mathrm{Fe}$ and $\mathrm{Sn}, J$. Dent. Res. to be published.

10) Miyagawa, Y.: X-ray diffraction at metal-ceramic interface (Part 2) Surface oxides of $88.5 \% \mathrm{Au}$ alloys containing $\mathrm{Fe}$, In, and $\mathrm{Sn}$ for porcelain fusing, J. D. A. M., 19: 15-27, 1978 (in Japanese).

11) Schneider, S.J., Roth, R.S., and Waring, J.L. reported in Levin, E.M., Robbins, C.R., and McMurdie, H.F. (editor): Phase diagrams for ceramists, The American Ceramic Society, Inc., 1964, p. 132.

12) Meijering, J.L.: Internal oxidation in alloys, Advan. Mater. Res., 5: 1-81, 1971.

13) Wagner, C.: Oxidation of alloys involving noble metals, J. Electrochem. Soc., 103: 571-580, 1956.

14) Ohno, H.: Studies on high temperature oxidation of noble metal alloys for dental use. (I) Formation of oxide layers and oxidation rate, J. D. A. M., 17: 297-312, 1976 (in Japanese).

15) Pethe, L.D., Mathur, H.B., and Biswas, A.B.: Transition from internal to external oxidation in indium-silver alloys, Canadian J. Chem. 46: 1187-1196.

16) Mackert, J.R., Ringle, R.D., and Fairhurst, C.W.: High-temperature behavior of a Pd-Ag alloy for porcelain, J. Dent. Res,. 62: 1229-1235, 1983. 
各種歯科用アマルガムの压縮強さの経時的変化

中井宏之, 鈴木一臣, 入江正郎, 新井浩一*, 橋本弘一*

㧫山大学茵学部茵科理工学講座

*城西菌科大学曾科材料学講座

各種隶科用アマルガムアロイの便化特性を压縮強さの 経時的測定により考察した。A. D. A. 規格 No. 1 の方式 によって作製された武片について測定をおこなったとと ろ, 強さの経時的な增加の㑯向は, アロイの組成や粓状 によって特幑のあるととが分かった。即ち, 粒状からい えば, 球状アロイが, 組成からいえば高銅型アロイが, それぞれ削片状厂ロイ, 徉来型アロイに比べてより短時 間内に強さが大きくなり最大值に達した。高銅型アロイ
のうちであ単一組成型は強さの発現が短時間内に起とる あのが多く, 他のアロイに比べて 1 時間強さが特に大き くなったが，30日強さは必ずしも大きくはなく，硬化が より短時間内と進行し終了するあのであるととがわかっ た。前に報告した硬さの経時的変化と比較してみると， 単一組成型高銅アロイの強さの増加は硬さの増加に比ぺ てゆるやかで，硬く胣い材料であるととが明らかとなっ た。

In と $\mathrm{Fe}$ を含む陶材焼付用金合金の酸化層の構造

大野弘機, 神澤康夫, 川島 功

東日本学園大学歯学部米科理工学教室

In と $\mathrm{Fe}$ を総量 $1.5 \mathrm{wt} \%$ 潦刀した陶材焼付用金合金 (85.5 wt\% Au) を $1000^{\circ} \mathrm{C}, 1 \mathrm{hr}$, 大気中で酸化させ, 单金属成分の添加量を変えた場合の酸化層の構造变化を $\mathrm{X}$ 線マイクロアナライザー, $\mathrm{X}$ 線回折, 反射電子回折で 解明した。その結果，Inを $0.15 \sim 1.5$ wt \% 含む合金 (1. 35 0 wt \% Fe) では, 一様な膜厚の外部酸化層が北 成されず，合金マトリックスが部分的に露出していると
とが明らかになった。 $\mathrm{In}_{2} \mathrm{O}_{3}, \mathrm{Fe}_{2} \mathrm{O}_{3}$, 未知の鉄酸化物の 3 つの酸化物が混合した状態で合金内部に析出した。そ の形態は，合金表面では針状に，また，合金内部では塊 状に結晶粒界に析出した。この合金の内部酸化は, これ らの析出した酸化物中を酸素イオンが拡散し, 移動する ことによって進行すると考えられた。

機能性モノマーの䨑科的応用（その 8 ）

\section{Alkylene glycol monomethacrylate の酸処理 \\ エナメル質括よびデンチン質への接着性 \\ 福島忠男, 川口 稔, 井上勇介, 宮崎光治, 堀部 隆 福岡歯科大学歯科理工学教室}

充填用レジンの歯質への接着性を改善するために， diluent として側鎖長の異なる Alkylene glycol monomethacrylate を 6 種合成し，2HEMA を加えたこれら モノマーの構造と物性の関係については前報で述べた。 本報では萰質への接着性と構造との関係をさらに検討し た。すなわち, リン酸で 1 分間処理した牛甬エナメル質 とリン酸, クエン酸および EDTA で 1 分間それぞれ処 理した牛蒾デンチン質へ， 7 種のモノマーから調製した Bonding agent を薄く塗布し，その上から即重レジンを
填入して作製した接着試料について, 室温に 3 時間放置 後, 水中浸漬30日後および Thermal cycling 後に引張 り試験を行って接着力を求めた。その結果，側鎖長の短 いあのが総体的にいずれあ接着性は優れていたが, 水中 浸漬後と Thermal cycling 処理後での接着力の低下は 4HBMA, 5HPeMA および 6HHeMA が小さく, 長期間 過酷な口腔内での使用にはてれらモノマーが diluent と して有効であると考えられる。 